\title{
On the Concept of Qu'ranic cdots in the Islamic Political Thought
}

\author{
Uthman ibn Afaq
}

ABSTRACT: It is written that The challenge posed to the revival of Islamic political thought is not only to take Islamic constitutional precepts from the original sources of the Islamic law(sharie ah), but also to make them relevant to contemporary life. This paper is a humble effort in that direction, its investigation being limited to the emergence of Islamic political science( siyasah al-shar ${ }^{\text {ei } i y y a h) ~ a s ~ a ~ d i s c i p l i n e ~ i n ~ I s l a m i c ~ s t u d i e s, ~ a n d ~ h o w ~ w e ~ d e f i n e s ~}$ Islamic political thought, phases of its development, elaboration of individual, political and common rights. Theimplication of this conceptfor political authority, the location of authority, the delegation of authority are then explored. The paper concludes with an explanation on the mechanism for delegation of authority in Islamic political thought.

\section{REFERENCES}

[1]. Schunk, D. H., \& DiBenedetto, M. K. (2020). Motivation and social cognitive theory. Contemporary Educational Psychology, 60, 101832.

[2]. Dorfman, B. S., \& Fortus, D. (2019). Students' self-efficacy for science in different school systems. Journal of Research in Science Teaching, 56(8), 1037-1059.

[3]. Brew, E. (2019). Determinants of low performance of female students In science subject: a survey of junior high schools in the Aowin district (Doctoral dissertation, University of Cape coast).

[4]. Falco, L. D., \& Summers, J. J. (2019). Social Persuasions in Math and Their Prediction of STEM Courses Self-Efficacy in Middle School. The Journal of Experimental Education, 1-18.

[5]. Ntarmah, A. H., Gyan, M. K., Gyedu, S., \& Cobbinah, E. The Predictive Power of Sources of Teacher Efficacy beliefs on Economics Teachers' Efficacy beliefs in the Implementation of Senior High School Economics Curriculum.

[6]. McBride, E., Oswald, W. W., Beck, L. A., \& Vashlishan Murray, A. (2019). "I'm just not that great at science": Science self-efficacy in arts and communication students. Journal of Research in Science Teaching.

[7]. Deel, C. M. (2019). Causal-Comparative Study of Reading Self-Efficacy of Senior High School Students Based on English Course Placement.

[8]. Probst, J. R. (2019). A Causal-Comparative Analysis of Mathematics Self-Efficacy Based on Gender and Math Acceleration.

[9]. La Ode Ahmad Jazuli, E. S., \& Syahrial, Z. The Effect of Brain Based Learning Strategies and Project Based Learning on Mathematics Learning Outcomes in Students of the Kinesthetic Learning Style Group.

[10]. Pei-Boon, O., Wan Jaafar, W. M., Chin-Siang, A., \& Nee-Nee, C. (2020). Psychometric Properties of the Sources of Counseling Self Efficacy in a Sample of Malaysian Secondary School Counselors. SAGE Open, 10(1), 2158244020902076.

[11]. Tahara, H. (2019). The Mathematical Expressions of Quranic Exegeses and the Mathematical Definition of the Quranic Correctness.

[12]. Tahara, H. (2019). Methodology to Prove the Quranic Correctness. International Journal of Humanities and Social Science Invention, 8(10), 01-02.

[13]. Tahara, H. (2019). The Quranic Studies by the Evaluation of Coefficients of Polynomials.

[14]. Tahara, H. (2019). Perspective about the Importance of Semantics to Prove the Quranic Correctness.

[15]. ibn Afaq, U. A Comparative Study of the Qu'ranic Correctness Claims between Wahid and Tahara.

[16]. ibn Afaq, U. About Unsteady Magnetopolar free Convection flow cdots in a Slip flow Regime.

[17]. ibn Afaq, U. About the Qu'ranic Study of cdots Naidu's Poetry.

[18]. ibn Afaq, U. About the Comparative and Qu'ranic Analysis of cdots in Nigeria 